\title{
Effect of the Plant Probiotic Bacteria on TIA Biosynthesis Pathway Gene Expression Profiling, Vinblastine and Vincristine Content in the Root of Catharanthus Roseus
}

Maryam Ahmadzadeh

Bu Ali Sina University Faculty of Agriculture

Amir Hossein Keshtkar ( $\square$ akesht@gmail.com )

Bu Ali Sina University Faculty of Agriculture https://orcid.org/0000-0002-5358-448X

Kobra Moslemkhany

Seed and Plant Certification and Registration Institute

Masoud Ahmadzadeh

University of Tehran University College of Agriculture and Natural Resources

\section{Research Article}

Keywords: Catharanthus roseus, Gene expression, HPLC, PGPR, Plant probiotic bacteria, qRT-PCR, Vinblastine, Vincristine

Posted Date: September 27th, 2021

DOI: https://doi.org/10.21203/rs.3.rs-863180/v1

License: (a) (i) This work is licensed under a Creative Commons Attribution 4.0 International License. Read Full License 


\section{Abstract}

Catharanthus roseus is the sole resource of vinblastine and vincristine, which are two of the biggest concerns of TIAs because of their powerful anticancer activities. Increasing the concentration of these alkaloids in various organs of the plant is one of the important goals in $C$. roseus breeding programs. Plant probiotic bacteria (PBB) act as biotic elicitors and can induce the synthesis of secondary products in plants. The purpose of this research is to study the individual and combined effects of $P$. fluorescens and $A$. brasilense on expression of the TIA biosynthetic pathway genes (G10H, DAT, T16H and CrPRX) using qRT-PCR and the content of vinblastine and vincristine alkaloids using HPLC method in roots of $C$. roseus. P. fluorescens drastically increased the content of vinblastine and vincristine alkaloids, compared to the control in the roots, up to 174 and $589(\mu \mathrm{g} / \mathrm{g})$, respectively. According to the molecular analysis, bacterium significantly increased the expression of more genes in the TIA biosynthetic pathway compared to the control. P. fluorescens increased the expression of the final gene of the biosynthetic pathway (CrPRX) 47.9 times compared to the control. Therefore, the findings indicate the coordination of transcriptional and metabolic outcomes. The same result was also observed for $A$. brasilense. According to the results, it can be concluded that, the seed priming and root of the seedling treatments of probiotic bacteria can be used as a good tool in the enhancement of alkaloid contents in medicinal plants, as it provides an eco-friendly approach.

\section{Introduction}

Medicinal plants are recognized as an important therapeutic tool to alleviate the ailments of human's kind (Sain and Sharma, 2013). Catharanthus roseus is one of the medicinal plant belonging to the family Apocynaceae (Almagro et al., 2015). C. roseus produces more than 130 types of terpenoid indole alkaloids (TIAs) (Gupta et al., 2007). This plant is the only source of vinblastine and vincristine, which are among the largest types of TIA due to their powerful anti-cancer activities (Zhu et al., 2014 and Sun et al., 2016). However, the production of these beneficial drugs has been limited due to their small amount in the plant (Pan, et al., 2010 and Almagro et al., 2015) and the major challenge in the pharmaceutical industry is the low production rate of these alkaloids (Soltani et al., 2020). Due to the pharmaceutical importance and the low content of vinblastine and the related alkaloid vincristine in plants. C. roseus, became one of the best-studied medicinal plants (Van der Heijden et al., 2004), and increasing the concentration of important medicinal alkaloids in its various organs is one of the most important goals in C. roseus breeding programs (Gupta et al., 2007).

All parts of the plant have alkaloid, but, maximum concentrations are found in the root organ, particularly during the flowering stage (Jaleel, et al., 2008). Therefore, this plant is considered as a very important medicinal plant in most pharmacopoeias due to the presence of valuable alkaloids in the shoots and roots.

The multi-step TIA biosynthetic pathway is quite complex and is under strict molecular regulation (Dutta et al., 2005). Many of the genes involved in this pathway of $C$. roseus have been cloned and sequenced for the analysis of their expression in various plant organs (Gupta et al., 2007). Critical early steps in the biosynthesis of TIAs include the reactions catalyzed by tryptophan decarboxylase (TDC), geraniol 10-hydroxylase (G10H), and strictosidine synthase (STR). TDC and G10H catalyze the first committed steps towards TIA biosynthesis in the indole and terpenoid precursor branches, respectively (Goklany et al., 2009). Strictosidine is the central intermediate in the biosynthesis of different TIAs, which is formed by the condensation of secologanin and tryptamine. Secologanin is derived from terpenoid (isoprenoid) biosynthetic pathway, while tryptamine is derived 
from indole biosynthetic pathway. Then various specific end products are produced by different routes during downstream process (Zhu et al., 2014). The downstream TIA pathway genes include deacetylvindoline-4-0acetyltransferase (DAT), Tabersonine 16-hydroxylase (T16H), and Catharanthus roseus peroxidase (CrPRX) (Wang et al., 2016) (Fig. 1).

TIA pathway is affected by biotic and abiotic factors (Favali, et al., 2004). According to some researchers, rhizosphere microorganisms act as biotic elicitors and can induce the synthesis of secondary products in plants (Sekar and Kandavel, 2010). Among these microorganisms, some have positive effects on plant growth promotion constituting the plant growth promoting rhizobacteria (PGPR) such as Azospirillum, Azotobacter, Pseudomonas fluorescens and several gram positive Bacillus sp (Jaleel et al., 2007b). These rhizobacterias induce the jasmonic acid and ethylene responses in plants (Pieterse et al., 2001 and Beneduzi et al. 2012). Tissue culture studies have also shown that the external application of these compounds has induced the production of secondary metabolites in some plant species (Sekar and Kandavel, 2010). Generally, the phytohormone jasmonic acid (JA) and its methyl ester, methyl jasmonate (MeJA), are major elicitors of TIA biosynthesis in C. roseus (Shen et al., 2017). The Naeem et al., (2017) review provides information regarding the role of potent PGRs such as gibberellic acid (GA3), in boosting the growth, metabolism, and other plant processes, particularly the production of anticancer alkaloids (vinblastine and vincristine) in $C$. roseus plants. Therefore, the mentioned bacteria can induce the synthesis of secondary metabolites in plants, through the production of phytohormones (Sekar and Kandavel, 2010). Singh et al., (2021) identifies the best combination of endophytes consisting of plant growth-promoting and alkaloid enhancing endophytes that can maximize the plant growth and TIAs yield in various $C$. roseus plant cultivars under field conditions.

It should be noted that the fluorescent strains of Pseudomonas and $A$. brasilense are both beneficial bacteria and have been mentioned in various sources as the most important and largest group of probiotic bacteria (Ahmadzadeh and Sharifi Tehrani 2021). A review of the resources shows that the only effect of these bacteria on growth parameters and metabolite levels has been studied in C. roseus (Jaleel et al., 2007b and Karthikeyan

et al., 2009), while, in the present study, the effect of rhizobacteria on the expression of TIA biosynthetic pathway genes in $C$. roseus was evaluated for the first time. The purpose of the research is investigation of the individual and combined effect of two species of rhizobacteria as a biotic treatment on expression some of the upstream and downstream TIA biosynthetic pathway genes, vinblastine and vincristine alkaloids content in roots of $C$. roseus.

\section{Materials And Methods}

\section{Bacterial strains and growth conditions}

The bacterial strains used in this study were Pseudomonas fluorescens and Azospirillum brasilense. The isolates provided from the Soil and Water Research Institute (Soil Biology Research Department), Karaj, Iran. The both of the bacteria were grown on nutrient agar (NA) for routine use. A single colony was transferred to $500 \mathrm{~mL}$ flasks containing NB grown aerobically in flasks on a rotating shaker (150 rpm) for $48 \mathrm{~h}$ (Karthikeyan et al., 2010). The bacterial suspensions were then diluted in distilled water to a final concentration of $10^{8}$ colony forming units (CFU) per milliliter, and the resulting suspensions were treated with $C$. roseus plants. Bacterial inoculation treatment was applied to the plant in three stages including seed, root inoculation and inoculation of soil around the roots. 


\section{Plant test}

The periwinkle seeds were provided by Pan American Seed Company (www.panamseed.com) and were surface sterilized in $0.1 \% \mathrm{NaClO}$ for 15 min with frequent shaking and rinsed thoroughly in distilled water to remove $\mathrm{NaClO}$. Surface-sterilized seeds were then soaked in a bacterial inoculum for 30 minutes, with shaking, and sown in culture trays, superficially. After irrigation, the culture trays were kept under plastic cover for complete absorption of moisture and natural light at a temperature of 20 to $25^{\circ} \mathrm{C}$. Seedlings after emergence and in the six-leaf stage were removed from the culture trays and immersed in a bacterial inoculum and then planted in separate pots $(15 \mathrm{~cm}$ diameter $\times 15 \mathrm{~cm}$ height), filled with a 2:1:1 mixture of farm soil, sand and peat, with the same weight $(500 \mathrm{~g})$.

Inoculation of root and soil around the roots were performed at the time of seedling transfer to the pot. For root inoculation, the root of the seedlings were washed with distilled water and then immersed in each of the inoculants for 20 minutes, in the six-leaf stage. Distilled water was used in equal volume with bacterial inoculation treatment as a control (no bacterial inoculation). The plants were uprooted at flowering stage the day $30^{\text {th }}$ after transferring from culture tray to pots for analyzing gene expression and estimation of vinblastine and vincristine content in the root.

\section{Influence of bacterial treatments on expression of $\mathrm{G} 10 \mathrm{H}, \mathrm{T} 16 \mathrm{H}$, DAT and CrPRX genes}

\section{RNA extraction, cDNA synthesis, and primer designing}

Root samples were flash-frozen in liquid nitrogen upon harvesting at the flowering stage and ground in liquid nitrogen using a mortar and pestle. Total RNA was extracted from $100 \mathrm{mg}$ of roots using the RibospinTM Seed/Fruit according to the manufacturer's instructions (GeneAll, South Korea). RNA concentration was quantified using the NanoDrop 2000c Spectrophotometer (Thermo Scientific NanoDrop 2000, USA) and were qualified by $1 \%$ agarose gel electrophoresis. The first strand cDNA was synthesized from $1 \mu \mathrm{g}$ of total RNA using the Hyperscript RT-PCR master mix ${ }^{\circledR}$ according to the manufacturer's instructions in the final volume of $10 \mu \mathrm{l}$ (GeneAll, South Korea). The cDNA was diluted to $100 \mathrm{ng} / \mu \mathrm{L}$ as the template for the real-time PCR analysis (Soltani et al., 2020).

The genes monitored in this study were $\mathrm{G} 10 \mathrm{H}$ (gene at the beginning of the pathway biosynthesis of TIAs, in the terpenoid pathway), DAT, T16H (vindoline pathway genes) and CrPRX (Terminal gene of the pathway). Primer sequences for target genes and the 40s ribosomal protein S9 (Rps9) reference gene were obtained from various resources (Table 1) and blasted in the National Center for Biotechnology Information (NCBI) genomic database (http://www.ncbi.nlm.nih.gov/tools/primer-blast/) (Table 1). Rps9 was validated as an appropriate housekeeping gene for the $C$. roseus by verifying the $\mathrm{Ct}$ profile for Rps9 remained nearly constant for all treatments (Goklany et al., 2009). To ensure the specific amplification of designed primers for these genes the $\mathrm{PCR}$ reaction was performed using $\mathrm{CDNA}$. 


\section{Table 1}

Name, accession number, Tm and sequence of primers used for qRT-PCR analysis in $C$. roseus

\begin{tabular}{|c|c|c|c|c|c|}
\hline $\begin{array}{l}\text { Gene } \\
\text { name }\end{array}$ & Primer sequence (5'-3') & $\underset{\left({ }^{\circ} \mathrm{C}\right)}{\operatorname{Tm}}$ & Accession & $\begin{array}{l}\text { PCR } \\
\text { Product } \\
(b p)^{1}\end{array}$ & Source \\
\hline \multirow[t]{2}{*}{$\mathrm{G} 10 \mathrm{H}$} & F:TAGCAGGGACGGACACAACATCAA & \multirow[t]{2}{*}{60} & \multirow[t]{2}{*}{ KF561461.1 } & \multirow[t]{2}{*}{304} & \multirow{2}{*}{$\begin{array}{l}\text { Goklany et al., } \\
2009\end{array}$} \\
\hline & R:TCACGTCCAATTGCCCAAGCATTC & & & & \\
\hline \multirow[t]{2}{*}{$\mathrm{T} 16 \mathrm{H}$} & F: GCTTCATCCACCAGTTCCAT & \multirow[t]{2}{*}{61} & \multirow[t]{2}{*}{ FJ647194.1 } & \multirow[t]{2}{*}{242} & \multirow[t]{2}{*}{ Wang et al., 2016} \\
\hline & R: CCGGACATATCCTTCTTCCA & & & & \\
\hline \multirow[t]{2}{*}{ DAT } & F: TTCCCTCCGGAAGCCATAGA & \multirow[t]{2}{*}{60} & \multirow[t]{2}{*}{ LN809931.1 } & \multirow[t]{2}{*}{125} & \multirow[t]{2}{*}{$\begin{array}{l}\text { Mokhaberi et al., } \\
2013\end{array}$} \\
\hline & R: GCTGATTTCCCTGCTACCGT & & & & \\
\hline \multirow[t]{2}{*}{ CrPRX } & F: GCAACATCTCCCAGACCACA & \multirow[t]{2}{*}{64} & \multirow[t]{2}{*}{ KT032115.1 } & \multirow[t]{2}{*}{117} & \multirow[t]{2}{*}{ Wang et al., 2016} \\
\hline & R: GTTCTCCCAACACTATGAGCACC & & & & \\
\hline \multirow[t]{2}{*}{ Rps92 } & F:TCCACCATGCCAGAGTGCTCATTA & \multirow[t]{2}{*}{64} & \multirow[t]{2}{*}{ A749993.1 } & \multirow[t]{2}{*}{203} & \multirow[t]{2}{*}{$\begin{array}{l}\text { Goklany et al., } \\
2009\end{array}$} \\
\hline & R:TCCATCACCACCAGATGCCTTCTT & & & & \\
\hline
\end{tabular}

1. Products were analyzed by running the RT-PCR products against a DNA ladder on a 1\% agarose gel.

2. Rps9 was used as the housekeeping gene.

G10H Geraniol-10-hydroxylase; T16HTabersonine 16-hydroxylase; DAT Deacetylvindoline-4Oacetyltransferase; CrPRX Catharanthus roseus peroxidase.

\section{Gene expression profiling and analysis}

The qRT-PCR analysis (Step One Plus Real-time PCR system, Applied Biosystems, USA) was performed using the specific primers to ensure amplification of the target genes. The expression level of the target and reference genes was determined using the RealQ Plus 2x Master Mix Green, High ROXTM. Three biological replications and two technical replications were considered for each gene. Each qRT-PCR reaction consisted of a mixture containing $16 \mathrm{ng} / \mu \mathrm{L}$ of cDNA ( $2 \mu \mathrm{l}$ of initial concentration in $100 \mathrm{ng} / \mu \mathrm{L}), 0.4 \mu \mathrm{M}$ of each of the forward and reverse primers, and Master Mix Green. The thermal cycling conditions included an initial denaturation step at 95 ${ }^{\circ} \mathrm{C}$ for $10 \mathrm{~min}$, followed by 40 cycles at $95^{\circ} \mathrm{C}$ for $10 \mathrm{~s}$, Temperature specific to each primer ${ }^{\circ} \mathrm{C}$ for $10 \mathrm{~s}$, and $72{ }^{\circ} \mathrm{C}$ for $15 \mathrm{~s}$.

\section{Vinblastine and vincristine extraction and quantification}

Collected root samples were dried at $58{ }^{\circ} \mathrm{C}$ for $48 \mathrm{~h}$ and pulverized in a mortar (Pan et al., 2010). Extraction of alkaloids were performed according to the method of Singh et al. (2000). Samples were applied in two copies for quantification of vinblastine and vincristine. Isolation and measurement of two alkaloids were performed using 
high performance liquid chromatography (HPLC) model Infinity 1260 (Agilent, USA) with RP-C18 column. The alkaloids were quantified by using the regression equation of calibration curve.

To prepare a standard sample, $1 \mathrm{~g}$ of vinblastine sulfate and $10 \mathrm{~g}$ of vincristine sulfate were dissolved in $10 \mathrm{ml}$ of distilled water. Then, the standard solution of vincristine and vinblastine $(1000 \mu \mathrm{g} / \mathrm{ml})$ was prepared by dissolving a certain amount of vinblastine sulfate and vincristine sulfate solution in methanol. The standard calibration curve was drawn. Finally, the amount of these two alkaloids in the samples was estimated by matching the standard curve.

The yield of alkaloids is calculated by multiplying the amount of alkaloids ( $\mu \mathrm{g} / \mathrm{g}$ of dry root weight) by the dry weight of the roots $(\mathrm{g})$.

\section{Statistical analysis}

In this research, the effect of two bacterial strains at four levels is studied. A control (no bacteria), P. fluorescens, $A$. brasilense and combined inoculation are investigated on $C$. roseus plants in a factorial experiment based on a randomized complete block design (RCBD) with three replications. The relative gene transcription was quantified using the comparative threshold cycle (CT) method and the data were analyzed using the RESTß software [Pfaffl et al., 2002] according to the $\Delta \Delta C T$ method [Livak and Schmittgen, 2001]. Analysis of metabolite data was performed using SAS Ver. 9.2. LSD (the least significant difference) procedure was used to compare the means.

\section{Results}

\section{Monitoring TIA gene expression in roots of $\mathrm{C}$. roseus}

The transcript level of G10H gene in the terpenoid pathway (Upstream TIA pathway gene) was significantly upregulated. Figure 2-A shows the effect of different treatments on the relative expression of $\mathrm{G} 10 \mathrm{H}$ gene compared to the control in the flowering stage of $C$. roseus. Individual inoculation treatments of two bacteria had a significant effect on $\mathrm{G} 10 \mathrm{H}$ gene expression. The highest transcript level was observed in $P$. fluorescens. In combined inoculation, no significant increase was observed in gene expression.

Among the studied treatments, $P$. fluorescens inoculation treatment increased the expression of T16H gene up to 22 times compared to the control. Combined inoculation resulted in increased gene expression, which was significant at the $5 \%$ probability level (Fig. 2-B).

According to Fig. 2-C, treatment with $P$. fluorescens had a significant effect on DAT gene expression compared to the control (34-fold). Combined inoculation showed a positive and significant effect at the level of $5 \%$ probability on the expression of the gene.

In the case of CrPRX gene, the final gene of TIA biosynthetic pathway, P. fluorescens and $A$. brasilense had a positive and significant effect on the $1 \%$ probability level and combined inoculation had a positive and significant effect on the 5\% probability level (Fig. 2-D). P. fluorescens increased the expression of CrPRX gene 47.9 times compared to the control. 


\section{Metabolite analysis in roots of $\mathrm{C}$. roseus}

Based on different concentrations of standard solutions injected into the device, the retention time (minutes) is specified for the vinblastine and vincristine alkaloids. The graphs of the other samples were interpreted based on the retention time of the alkaloids.

HPLC analyzing the extracts of $C$. roseus root inoculated with bacterial treatments showed a significant difference for both alkaloids and vincristine yield per plant (Table 2). According to mean comparison (Table 3 and Fig. 3), P. fluorescens and $A$. brasilense, respectively, were characterized as the best treatments to induce significant production of vincristine and vinblastine alkaloids. In addition, these treatments individually caused increase of vincristine yield per plants root in the same manner as amount per gram of dry root weight.

Comparatively, the vincristine content was estimated at approximately $589 \mu \mathrm{g} / \mathrm{g}$ of dry root weight in plant roots treated with $P$. fluorescens indicating remarkable value, which was significantly more than the control. Also, applying this treatment increased the vinblastine contents by up to $175 \mu \mathrm{g} / \mathrm{g}$ of root dry weight compared to the control. However, combined inoculation elicited the minimum production of vinblastine alkaloid, which is not significant content compared to the control sample.

Table 2

Analysis of variance of the effect of bacterial inoculation treatment on vinblastine and vincristine in the root and alkaloids yield per plant of C. roseus

\begin{tabular}{|lcllll|}
\hline Source of variation & df & Vinblastine & Vincristine & $\begin{array}{l}\text { Vinblastine yield per } \\
\text { plant }\end{array}$ & $\begin{array}{l}\text { Vincristine yield per } \\
\text { plant }\end{array}$ \\
\hline $\begin{array}{l}\text { Bacterial inoculation } \\
\text { Error }\end{array}$ & 3 & $38499.49^{* *}$ & $216646.22^{* *}$ & $1321.22^{\mathrm{Ns}}$ & $6905.43^{*}$ \\
\hline $\begin{array}{l}\text { Coefficient of } \\
\text { variation \% }\end{array}$ & 4 & 611.88 & 3460.33 & 285.05 & 1017.74 \\
\hline \begin{tabular}{l} 
Ns ${ }^{*},{ }^{* *}$ : Non-significant, significant at the 5\% and 1\% probability, respectively level. \\
\hline
\end{tabular} & -6.71 & 6.83 & 23.33 & 18.99 \\
\hline
\end{tabular}

Table 3

Mean comparisons of vinblastin and vincristine alkaloids in the roots and vincristine yield per plant of $\mathrm{C}$. roseus as influenced by different bacteria

\begin{tabular}{|lllll|}
\hline No. & Bacterial inoculation & Vinblastine $(\boldsymbol{\mu g} / \mathbf{g})$ & Vincristine $(\boldsymbol{\mu g} / \mathbf{g})$ & Vincristine yield per plant \\
\hline 1 & Control & $339.28 \mathrm{c}$ & $649.72 \mathrm{c}$ & $142.10 \mathrm{~b}$ \\
\hline 2 & Combined inoculation & $189.85 \mathrm{~d}$ & $529.07 \mathrm{c}$ & $111.73 \mathrm{~b}$ \\
\hline 3 & P.f & $513.22 \mathrm{a}$ & $1238.71 \mathrm{a}$ & $248.74 \mathrm{a}$ \\
\hline 4 & A.b & $432.03 \mathrm{~b}$ & $1026.78 \mathrm{~b}$ & $169.42 \mathrm{ab}$ \\
\hline
\end{tabular}




\section{Discussion}

Given the molecular results, inoculation of two bacteria treatments individually enhanced the expression of the interested genes in the roots of $C$. roseus. Among them, $P$. fluorescens had a positive and significant effect on the expression of genes involved in first step $(\mathrm{G} 10 \mathrm{H})$ and the last step $(\mathrm{T} 16 \mathrm{H}, \mathrm{DAT}$ and $\mathrm{CrPRX})$ of the biosynthetic pathway. Previously, up-regulation of TDC genes had been reported in the roots of $C$. roseus treated with this elicitor (Ahmadzadeh et al., in press). Li et al. (2013) found the significant changes in the expression level of genes involved in the TIA biosynthesis, such as $\mathrm{Tdc}$ and $\mathrm{G} 10 \mathrm{H}$, by overexpressing the transcription factor ORCA2 in the hairy roots of $C$. roseus. In other words, these gene have a common transcription factor. Liu et al. (2017) showed that the transcription factors ORCA2 and ORCA3 regulate the expression of G10H and TDC genes. These transcriptional factors are activated in response to methyl jasmonate and jasmonic acid. However, in the present study, they probably were activated under the bacterial treatments, especially $P$. fluorescens, in the roots. Researches revealed that the $\mathrm{G} 10 \mathrm{H}$ promoter contains unique binding sites of several transcriptional factors, suggesting that the $\mathrm{G} 10 \mathrm{H}$ promoter may be regulated by a different transcriptional cascade (Suttipanta et al. 2007).

In the vindoline biosynthesis pathway, the two genes $\mathrm{T} 16 \mathrm{H}$ and DAT involved in first and last steps respectively (Shabani et al., 2014) were elected for investigation. Owing to the production of vindoline with organ-dependent manner in green tissues, the expression of genes is not predicted through this branch of TIA biosynthesis pathway in root tissue under normal conditions (Dutta et al., 2005). However, molecular analysis demonstrated the expression of both genes in the roots under all treatments. The expression of some genes in this pathway, including the D4h in root tissue, has already been reported by Dutta et al. (2005). In order to prove the correspondence of observed hybridization signals with the real expression of the $\mathrm{D} 4 \mathrm{H}$ gene in the root, they sequenced RT-PCR products and finally obtained more than $99 \%$ homology by blasting with sequences in the data bank (GenBank Acc. No. 004847).

In this study, expression of T16H and DAT genes in the root was affected by $P$. fluorescens and combine inoculation treatments. Also, the response of these two genes to all used treatments was almost the same. Thus, the treatments that increased the expression of $\mathrm{T} 16 \mathrm{H}$ gene also increased the expression of DAT gene in the root. This result was not unexpected. This is because these two genes are in a branch of the biosynthetic pathway and it is possible that they have a common promoter to regulate expression or are activated by a common transcription factor. The possibility of co-response of some biosynthetic pathway genes of TIA to elicitors has also been mentioned in other reports. The expression of several genes involved in the biosynthetic pathway of indole alkaloids, including Str and Tdc, is coordinately induced by fungal elicitors such as yeast extract (Pauw et al. 2004).

The CrPRX gene is the final gene of the TIA biosynthetic pathway and encodes the enzyme anhydrovinblastine synthase. The product of this gene combines the two substances catharanthine and vindoline and it causes the formation of vinblastine and eventually vincristine (Goklani et al., 2009). CrPRX gene expression in root in response to all treatments was significantly increased compared to the control, but the most effective treatment was $P$. fluorescens. In the study of Wang et al., 2016, the transcript level of CrPRX in C. roseus increased in response to different concentrations of ethephon. Maximal amounts of CrPRX transcripts were detected in seedlings treated by $100 \mu \mathrm{M}$ ethephon. Since the studied rhizobacteria increase the susceptibility of the plant to 
ethylene (Beneduzi et al., 2012), it may be possible to influence the expression of TIA biosynthetic pathway genes in this way.

Overall, $P$. fluorescens was effective than other treatments in root and caused the significant up-regulation of studied genes, particularly last step gene, CrPRX, compared to the control plant. In sequent, $A$. brasilense treatment was able to increase the expression of $\mathrm{G} 10 \mathrm{H}$ and $\mathrm{CrPRX}$, significantly.

van der Fits and Memelinc, (2000) showed that methyl jasmonate (MJ) treatment stimulated TIA metabolism in $C$. roseus cell suspension and increased the expression of all genes implicated in the TIA biosynthetic pathway. In addition, the transcription factor ORCA3 was activated in response to $\mathrm{MJ}$, which in turn regulated the expression of some other genes in this pathway, including the STR. Suttipanta (2011) studied the transcription factor WRKY in the $C$. roseus plant, which is expressed predominantly in roots and also in response to phytohormones such as jasmonate, gibberellin, and ethylene. They demonstrated that a high expression of transcription factor CrWRKY2 in response to methyl jasmonate in the hair roots culture of $C$. roseus up-regulates several TIA pathway genes $\varangle$.Besides, it promoted the expression level of the transcription factor activating ORCA3 and the inhibitor of ZCT. Simultaneous induction of activators and inhibitors may be necessary to activate or repress some genes in response to elicitors (Shabani et al., 2014). It is noteworthy that some transcription factors are tissue specific, and some treatments are involved in the simultaneous induction of transcription factors of either activators or inhibitors. According to Pattra et al. (2018), inhibitors such as JAZs and RMT1 mediate the interaction of CrMYC2 and BIS regulators, as well as balance the metabolic flux of TIA. Zhang et al. (2011) showed that application of methyl jasmonate increases the expression of Tdc, G10H, Str, etc., genes in the biosynthetic pathway of TIA in the $C$. roseus. Another study revealed that ethylene treatment has a positive effect on C. roseus alkaloids at transcriptional and metabolic levels (Wang et al., 2016). Also, Shabani et al. (2014) found that some genes in the TIA pathway, such as the G10H gene, play critical role in responses to ethylene. Papon et al. (2005) reported high expression of this gene in response to cytokine and ethylene. Similarly, in this study, inoculation treatments individually had positive and significant effects on $\mathrm{G} 10 \mathrm{H}$ in roots. In agreement with these results and previous research, it can be suggested that bacterial inoculation treatments by producing cytokinin hormone or increasing plant susceptibility to ethylene in the root, have upregulated the $\mathrm{G} 10 \mathrm{H}$ gene in conjunction with other genes studied.

Given the results, it could be inferred that exposure of $C$. roseus to bacterial inoculation treatment probably induced the production of hormones such as gibberellin and cytokinin, as well as activated the jasmonic acid and ethylene responses. These increased the expression level of transcription factor CrWRKT2, subsequently activators ORCA3 and ORCA2 in conjunction with some inhibitors, which in turn influenced the expression level of genes involved in the TIA biosynthetic pathway. Considering the positive correlation between relative expression level of these gene and the accumulation of corresponding alkaloids in C. roseus (Dutta et al., 2005; Goklani et al., 2009; Jaggi et al., 2011 and Wang et al. 2016), it can be concluded that up-regulation of G10H, DAT, T16H and CrPRX genes under these treatments, especially by $P$. fluorescens, can result in a higher production rate of vinblastine and vincristine alkaloids as final products in the TIA biosynthetic pathway. As an example, it is shown that an increase in the expression level of DAT has been found to result in the accumulation of vinblastine and vincristine alkaloids (Wang et al., 2012 and Khataee et al., 2019). In this case, metabolite studies were performed in the plant. 
Root inoculation with plant probiotic bacteria promoted significant increase in growth and alkaloid content (Karthikeyan et al., 2010). Some studies have shown that different types of probiotic bacteria have a positive effect on alkaloid content in the root of $C$. roseus (Jaleel et al., 2007a; Jaleel et al., 2009; Karthikeyan et al., 2010). Jaleel et al. (2007b) studied the effect of $P$. fluorescens along with drought stress on vegetative traits, and ajmalicine content in roots of $C$. roseus plant. They suggested that ajmalicine content increased significantly due to exposure of drought-treated plants with $P$. fluorescens compared to non-treated plants and control under drought stress. Experimentally, Jaleel et al. (2009) showed that supplementing plant growth regulators as the same as $P$. fluorescens elicitor significantly changed the constituents of metabolites (ajmalycin, serpentine, catarantine, and vindoline) in the roots of $C$. roseus. Karthikeyan et al. (2009) also found, by inoculating $C$. roseus seeds and seedlings with $P$. fluorescens and $A$. brasilense separately or in combination that bacteria can be used as a suitable agent to increase alkaloids in $C$. roseus roots. Also, the effect of these beneficial bacterial strains has been demonstrated on alkaloid contents of Hyoscymus niger L. and increasing the hyoscyamine and scopolamine yield in roots and shoots (Ghorbanpour et al., 2013).

To comparative analysis of molecular and metabolite results, all results were presented in Table 4. As seen in this table, $P$. fluorescens by increasing the expression of all studied genes in the biosynthetic pathway and $A$. brasilense by increasing the expression of gene at the beginning $(\mathrm{G} 10 \mathrm{H})$ and end of the pathway (CrPRX) were able to significantly increase the levels of both vinblastine and vincristine alkaloids compared to the control.

Table 4

Comparative analysis of molecular and metabolite evaluations in the roots of $\mathrm{C}$. roseus inoculated with bacteria relative to control

$\begin{array}{lll}\begin{array}{l}\text { Bacterial } \\ \text { inoculation }\end{array} & \text { Genes expression relative to control } & \begin{array}{l}\text { Alkaloids amount } \\ \text { relative to control }\end{array}\end{array}$

treatments

\begin{tabular}{|c|c|c|c|c|c|c|c|}
\hline \multirow{3}{*}{$\begin{array}{l}\text { Upstream } \\
\text { TIA } \\
\text { pathway } \\
\text { gene } \\
\text { G10H }\end{array}$} & \multicolumn{4}{|c|}{ Downstream TIA pathway genes } & \multirow{3}{*}{$\begin{array}{l}\text { Vinblastine } \\
(\mu \mathrm{g} / \mathrm{g})\end{array}$} & \multirow{3}{*}{$\begin{array}{l}\text { Vincristine } \\
(\mu \mathrm{g} / \mathrm{g})\end{array}$} & \multirow[b]{4}{*}{ Unchanged } \\
\hline & \multicolumn{3}{|c|}{ Vindoline pathway } & \multirow{2}{*}{$\begin{array}{l}\text { Terminal } \\
\text { gene }\end{array}$} & & & \\
\hline & $\mathrm{T} 16 \mathrm{H}$ & DAT & CrPRX & & & & \\
\hline $\begin{array}{l}\text { Combined } \\
\text { inoculation }\end{array}$ & Increase $\mathrm{Ns}^{\mathrm{N}}$ & Increase $e^{*}$ & Increase $e^{*}$ & Increase ${ }^{*}$ & & Decrease $^{*}$ & \\
\hline $\begin{array}{l}P \\
\text { fluorescens }\end{array}$ & Increase ${ }^{\star \star}$ & Increase ${ }^{\star \star}$ & Increase ${ }^{\star \star}$ & Increase ${ }^{* \star}$ & & Increase $^{*}$ & Increase $^{*}$ \\
\hline $\begin{array}{l}\text { A. } \\
\text { brasilense }\end{array}$ & Increase ${ }^{\star \star}$ & Increase $\mathrm{Ns}^{\mathrm{N}}$ & Increase $\mathrm{Ns}^{\mathrm{N}}$ & Increase ${ }^{* *}$ & & Increase ${ }^{*}$ & Increase $^{*}$ \\
\hline \multicolumn{8}{|c|}{ Gene expression was measured relative to the control sample (no bacterial inoculation). } \\
\hline \multicolumn{8}{|c|}{ Ns, ${ }_{,}^{*}{ }^{* *}$ : Non-significant, significant at the level of $5 \%$ and $1 \%$ probability, respectively. } \\
\hline \multicolumn{8}{|c|}{ P.F: P. fluorescens and A.b: A. brasilense } \\
\hline
\end{tabular}

\section{Conclusions}


In the present study, $P$. fluorescens drastically increased the content of two alkaloids vinblastine and vincristine, compared to the control and other bacterial treatments in the roots of $C$. roseus. A review of the results of molecular analysis showed that the bacterium significantly increased the expression of more genes in the TIA biosynthetic pathway compared to the control. Therefore, the positive effect of this treatment on the amount of evaluated alkaloids indicates the compatibility of the results of transcription and metabolic. The same result was observed for $A$. brasilense (Table 5). From the results of this investigation, it can be concluded that, the seed priming and seedling treatments of plant probiotic bacteria can be used as a good tool in the enhancement of alkaloid contents in medicinal plants, as it provides an eco-friendly approach.

Considering the positive effect of bacteria on two important alkaloids of $C$. roseus, the results of this research can be considered an important step in the pharmaceutical industry.

\section{Abbreviations}

CFU colony forming units

CrPRX Catharanthus roseus peroxidase

DAT Deacetylvindoline-4-0-acetyltransferase

D4H Desacetoxyvindoline-4-hydroxylase

G10H Geraniol-10-hydroxylase

HPLC High-performance liquid chromatography

PBB Plant probiotic bacteria

PGPR Plant growth promoting rhizobacteria

qRT-PCR Quantitative reverse transcription PCR

RSP9 40 s ribosomal protein S9

TIAs Terpenoid indole alkaloids

\section{Declarations}

\section{Authors' Contributions}

Maryam Ahmadzdeh conducted the experiments and drafted the manuscript; Amir Hossein Keshtkar conceived the idea, performed the statistical analysis and edited the manuscript; Kobra Moslemkhany and Masoud Ahmadzadeh helped in the design of some experiments and assisted in interpreting the data; all authors read and approved the final manuscript.

\section{Compliance with ethical standards}




\section{Conflicts of interest}

The authors report no conflicts of interest.

\section{Ethical approval}

All procedures performed in this study did not involve human or animal participants.

\section{References}

1. Ahmadzadeh M, and Sharifi Tehrani A (2021). Plant probiotic bacteria. University of Tehran Press. 630 Pages. (In Persian)

2. Ahmadzadeh M, Keshtkar AH, Moslemkhany K, Ahmadzadeh M (2021). Evaluation of water deficite stress and plant growth-promoting rhizobacteria effect on some of morphological traits and expression level of Tdc and Str at the root of Catharanthus roseus. Journal of Plant Research (Iranian Journal of Biology), in press. (In Persian)

3. Almagro L, Fernández-Pérez F, Pedreño, M A (2015). Indole alkaloids from Catharanthus roseus: bioproduction and their effect on human health. Molecules, 20: 2973-3000

4. Beneduzi A, Ambrosini A, Passaglia LMP (2012) Plant growth-promoting rhizobacteria (PGPR): Their potential as antagonists and biocontrol agents. Genetics and Molecular Biology, 35 (4): 1044-1051

5. Dutta A, Batra J, Pandey-Rai S, Singh D, Kumar S, Sen J (2005) Expression of terpenoid indole alkaloid biosynthetic pathway genes corresponds to accumulation of related alkaloids in Catharanthus roseus (L.) G. Don. Planta, 220 (3): 376-383

6. Favali MA, Musetti R, Benvenuti S, Bianch, A, Pressacco L (2004) Catharanthus roseus L. plants and explants infected with phytoplasmas: alkaloid production and structural observations". Protoplasma, 223 (1): 45-51

7. Ghorbanpour M, Hatami M, Khavazi K (2013) Role of plant growth promoting rhizobacteria on antioxidant enzyme activities and tropane alkaloid production of Hyoscyamus niger under water deficit stress. Turkish Journal of Biology, 37:350-360

8. Goklany Sh, Loring RH, Glick J, Lee-Parsons CWT (2009) Assessing the limitations to terpenoid indole alkaloid biosynthesis in Catharanthus roseus hairy root cultures through gene expression profiling and precursor feeding". Biotechnology Progress, 25 (5): 1289- 1296

9. Gupta S, Pandey-Rai S, Srivastava S, Naithani SC, Prasad M, Kumar S (2007) Construction of genetic linkage map of the medicinal and ornamental plant Catharanthus roseus. Journal of Genetics, 86 (3): 259268

10. Jaggi M, Kumar S, Sinha AK (2011) Overexpression of an apoplastic peroxidase gene CrPrx in transgenic hairy root lines of Catharanthus roseus. Applied microbiology and biotechnology, 90 (3): 1005-1016

11. Jaleel CA, Gopi R, Gomathinayagam M, Panneerselvam R (2009) Traditional and non-traditional plant growth regulators alters phytochemical constituents in Catharanthus roseus. Process Biochemistry, 44 (2): 205-209 
12. Jaleel CA, Gopi R, Manivannan P, Sankar B, Kishorekumar A, and Panneerselvam R (2007a) Antioxidant potentials and ajmalicine accumulation in Catharanthus roseus after treatment with giberellic acid. Colloids and surfaces B: Biointerfaces, 60 (2): 195-200

13. Jaleel CA, Manivannan P, Sankar B, Kishorekumar A, Gopi R, Somasundaram R, Panneerselvam R (2007b) Pseudomonas fluorescens enhances biomass yield and ajmalicine production in Catharanthus roseus under water deficit stress. Colloids and Surfaces B: Biointerfaces, 60 (1): 7-11

14. Jaleel CA, Sankar B, Sridharan R, Panneerselvam R (2008) Soil salinity alters growth, chlorophyll content, and secondary metabolite accumulation in Catharanthus roseus. Turkish Journal of Biology, 32 (2): 79-83

15. Karthikeyan B, Jaleel CA, Azooz MM (2009) Individual and combined effects of Azospirillum brasilense and Pseudomonas fluorescens on biomass yield and ajmalicine production in Catharanthus roseus. Academic Journal of Plant Sciences, 2 (2): 69-73

16. Karthikeyan B, Joe MM, Jaleel CA, Deiveekasundaram M (2010) Effect of root inoculation with plant growth promoting rhizobacteria (PGPR) on plant growth, alkaloid content and nutrient control of Catharanthus roseus (L.) G. Don. Natura Croatica, 19 (1): 205-212

17. Khataee E, Karimi F, Razavi K (2019) Alkaloids production and antioxidant properties in Catharanthus roseus (L.) G. Don. Shoots and study of alkaloid biosynthesis-related gene expression levels in response to methyl jasmonate and putrescine treatments as ecofriendly elicitors. Biologia Futura 70(1):38-46

18. Li CY, Leopold AL, Sander GW, Shanks JV, Zhao L, Gibson SI (2013) The ORCA2 transcription factor plays a key role in regulation of the terpenoid indole alkaloid pathway. BMC Plant Biology, 13 (1): 1-17

19. Liu J, Cai J, Wang R, Yang S (2017) Transcriptional regulation and transport of terpenoid indole alkaloid in Catharanthus roseus: exploration of new research directions. International Journal of Molecular Sciences, 18, 53. $20 \mathrm{P}$.

20. Livak KJ, Schmittgen TD (2001) Analysis of relative gene expression data using real-time quantitative PCR and the $2-\triangle \triangle C T$ method. Methods 25(4):402-408

21. Mokhaberi A, Ahmadi J, Mafakheri S (2013) The expression profile of D4H and DAT genes in Catharanthus roseus in response to drought, salinity and salicylic acid. Iran J Genet Plant Breed 2(2):38-46

22. Naeem M, Aftab T, Idrees M, Alam MM, Khan MMA, Uddin M (2017) Plant efficacy and alkaloids production in sadabahar (Catharanthus roseus L.): Role of potent PGRs and mineral nutrients. In Catharanthus roseus (pp. 35-57). Springer, Cham

23. Pan Q, Chen Y, Wang Q, Yuan F, Xing S, Tian Y, Zhao J, Sun X, Tang K (2010) Effect of plant growth regulators on the biosynthesis of vinblastine, vindoline and catharanthine in Catharanthus roseus. Plant Growth Regul 60(2):133-141

24. Papon N, Bremer J, Vansiri A, Andreu F, Rideau M, Crèche J (2005) Cytokinin and ethylene control indole alkaloid production at the level of the MEP/terpenoid pathway in Catharanthus roseus suspension cells. Planta Med 71(06):572-574

25. Patra B, Pattanaik S, Schluttenhofer C, Yuan L (2018) A network of jasmonate-responsive bHLH factors modulate monoterpenoid indole alkaloid biosynthesis in Catharanthus roseus. New Phytologist, 217 (4): 1566-1581

26. Pauw B, Hilliou FA, Martin VS, Chatel G, de Wolf CJ, Champion A, et al. (2004) Zinc finger proteins act as transcriptional repressors of alkaloid biosynthesis genes in Catharanthus roseus. Journal of Biological 
Chemistry, 279 (51): 52940-52948

27. Pfaffl MW, Horgan GW, Dempfle L (2002) Relative expression software tool (REST@) for group-wise comparison and statistical analysis of relative expression results in real-time PCR. Nucleic Acids Res 30(9):e36-e36

28. Pieterse CM, Van Pelt JA, Van Wees SC, Ton J, Léon-Kloosterziel KM, Keurentjes JJ, et al. (2001) Rhizobacteria-mediated induced systemic resistance: triggering, signalling and expression. European Journal of Plant Pathology, 107 (1): 51-61

29. Sain M, Sharma V (2013) Catharanthus roseus (an anti-cancerous drug yielding plant). A review of potential therapeutic properties. Int J Pure App Biosci 1(6):139-142

30. Sekar S, Kandavel D (2010) Interaction of Plant Growth Promoting Rhizobacteria (PGPR) and Endophytes with Medicinal Plants for Phytochemicals. Journal of Phytology, 2 (7): 91-100

31. Shabani, M., Farsi M, Mirshamsi Kakhki A (2014) Evaluation of ethylene effect on expression level of T16H, G10H, DAT and AVLBS genes in Catharanthus roseus. Iranian Genetics Society. Moden Genetics, 9 (2): 151160 (In Persian)

32. Shen EM, Singh SK, Ghosh JS, Patra B, Paul P, Yuan L, Pattanaik S (2017) The miRNAome of Catharanthus roseus: identification, expression analysis, and potential roles of microRNAs in regulation of terpenoid indole alkaloid biosynthesis. Scientific reports, 7(1): 1-13

33. Singh DV, Maithy A, Verma RK, Gupta MM, Kumar S (2000) Simultaneous determination of Catharanthus alkaloids using reversed phase high performance liquid chromatography. Journal of Liquid Chromatography and Related Technologies, 23 (4): 601-607

34. Singh S, Pandey SS, Tiwari R, Pandey A, Shanker K, Kalra A (2021) Endophytic consortium with growthpromoting and alkaloid enhancing capabilities enhance key terpenoid indole alkaloids of Catharanthus roseus in the winter and summer seasons. Industrial Crops and Products, 166: 113437

35. Soltani N, Nazarian-Firouzabadi F, Shafeinia A, Sadr AS, Shirali M (2020) The expression of Terpenoid Indole Alkaloid (TIAs) pathway genes in Catharanthus roseus in response to salicylic acid treatment. Molecular Biology Reports, 47(9): 7009-7016

36. Sun J, Manmathan H, Sun C, Peebles CA (2016) Examining the transcriptional response of overexpressing anthranilate synthase in the hairy roots of an important medicinal plant Catharanthus roseus by RNA-sEq. BMC Plant Biol 16(1):108

37. Suttipanta N (2011) Characterzation of G10H promoter and isolation of WRKY transcription factors involved in Catharanthus terpenoid indol alkaloid biosynthesis pathway. Dissertation, University of Kentucky, USA. Plant Physiology, 157: 2081-2093

38. Suttipanta N, Pattanaik S, Gunjan S, Xie CH, Littleton J, Yuan L (2007) Promoter analysis of the Catharanthus roseus geraniol 10-hydroxylase gene involved in terpenoid indole alkaloid biosynthesis. Biochim Biophys Acta 1769:139-148

39. Van der Fits L, Memelink J (2000) ORCA3, a jasmonate-responsive transcriptional regulator of plant primary and secondary metabolism. Science, 289 (5477): 295-297

40. Van der Heijden R, Jacobs DI, Snoeijer W, Hallard D, Verpoorte R (2004) The Catharanthus alkaloids: pharmacognosy and biotechnology. Current Medicinal Chemistry, 11 (5): 607-628 
41. Wang Q, Xing S, Pan Q, Yuan F, Zhao J, Tian Y, Chen Y, Wang G, Tang K (2012) Development of efficient Catharanthus roseus regeneration and transformation system using Agrobacterium tumefaciens and hypocotyls as explants. BMC Biotechnol 12(1):34

42. Wang X, Pan Y, Chang B, Hu Y, Guo X, Tang Z (2016) Ethylene-induced vinblastine accumulation is related to activate expression of downstream TIA pathway genes in Catharanthus roseus. Hindawi Publishing Corporation. BioMed Research International, 8 P.

43. Zhang H, Hedhili S, Montiel G, Zhang Y, Chatel G, Pre M, et al. (2011) The basic helix-loop-helix transcription factor CrMYC2 controls the jasmonate responsive expression of the ORCA genes that regulate alkaloid biosynthesis in Catharanthus roseus. Plant Journal, 67: 61-71

44. Zhu X, Zeng X, Sun C, Chen S (2014) Biosynthetic pathway of terpenoid indole alkaloids in Catharanthus roseus. Frontiers of medicine, 8 (3): 285-293

\section{Figures}

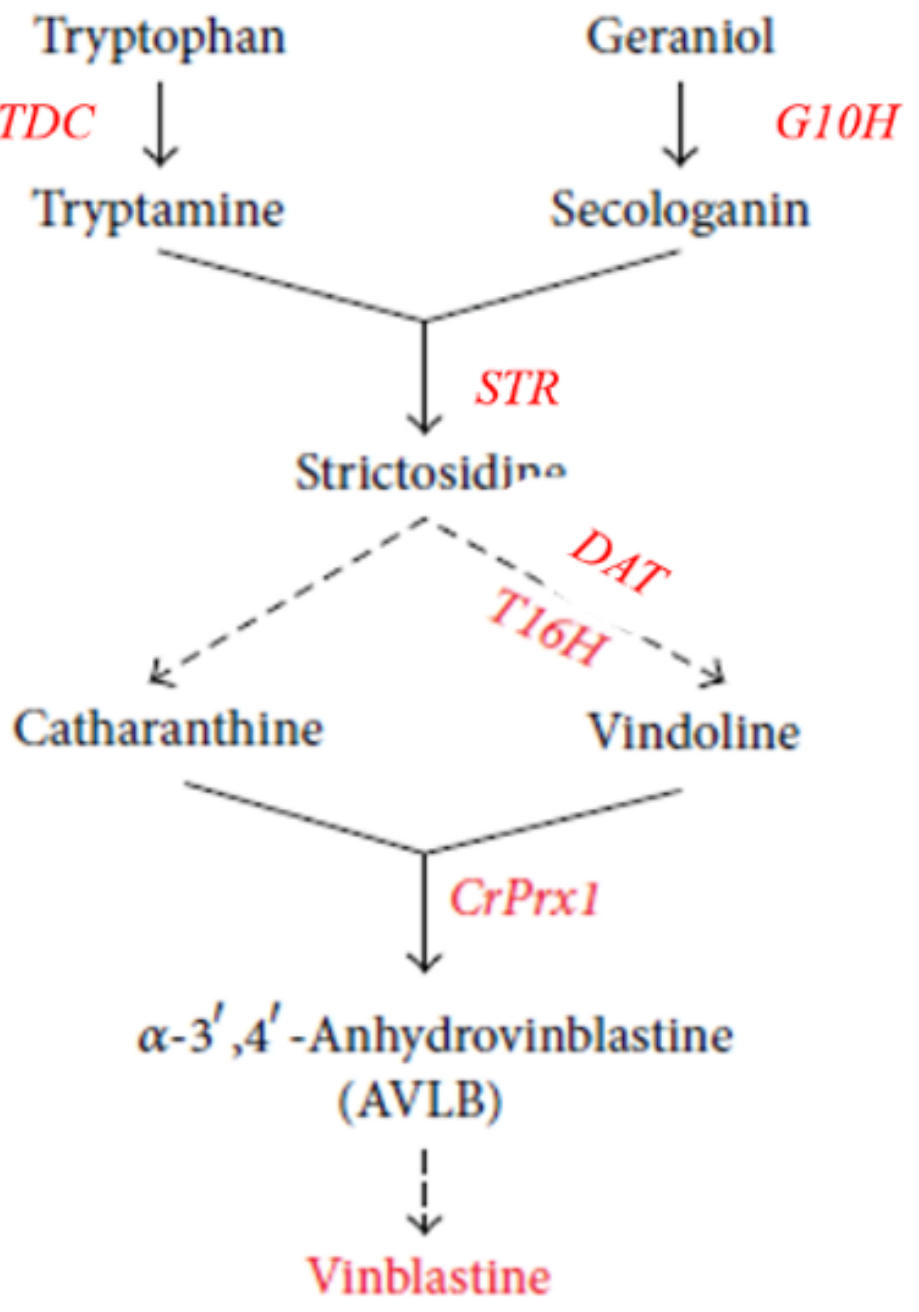

\section{Figure 1}

The pathway of terpenoid indole alkaloids biosynthesis in Catharanthus roseus. (Taken from Wang et al., 2016) 
A Terpenoid pathway gene

(Upstream TIA pathway gene)

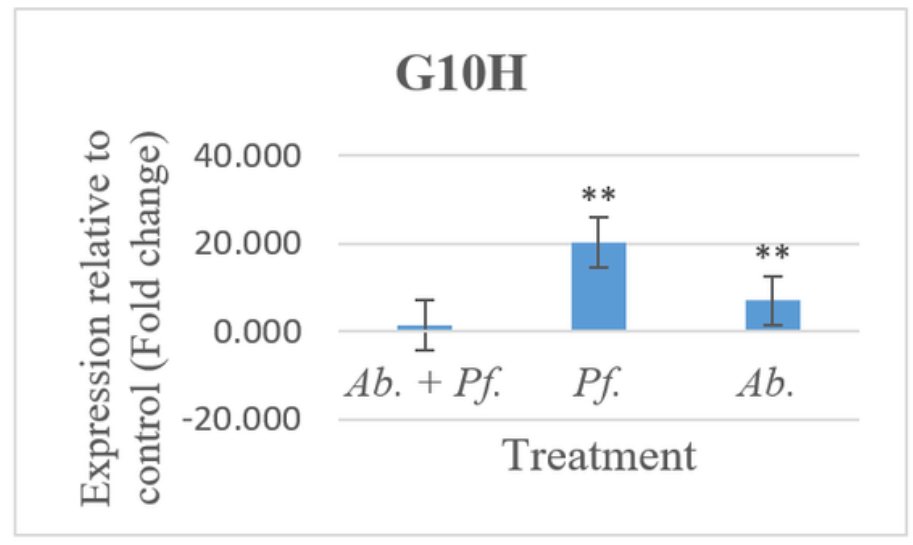

C

Vindoline pathway gene

(Downstream TIA pathway genes)

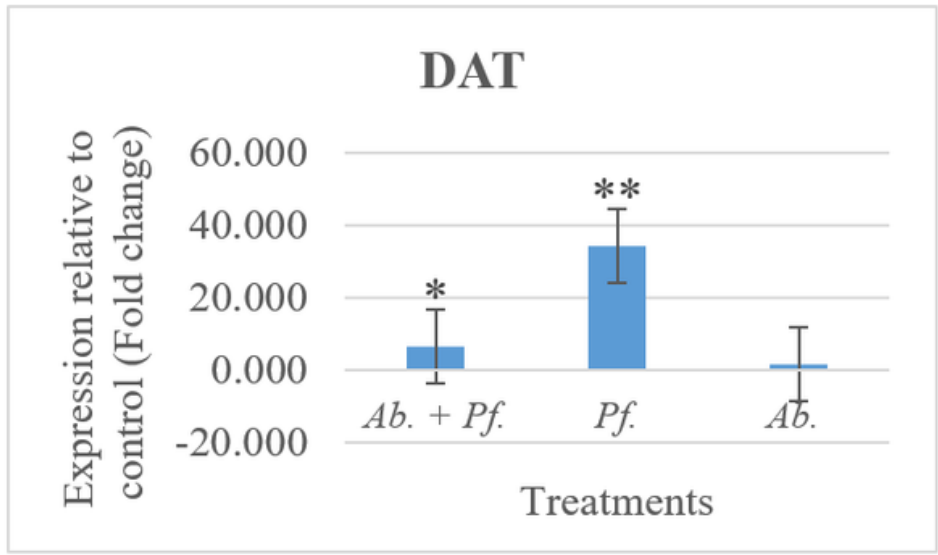

B

Vindoline pathway gene

(Downstream TIA pathway genes)

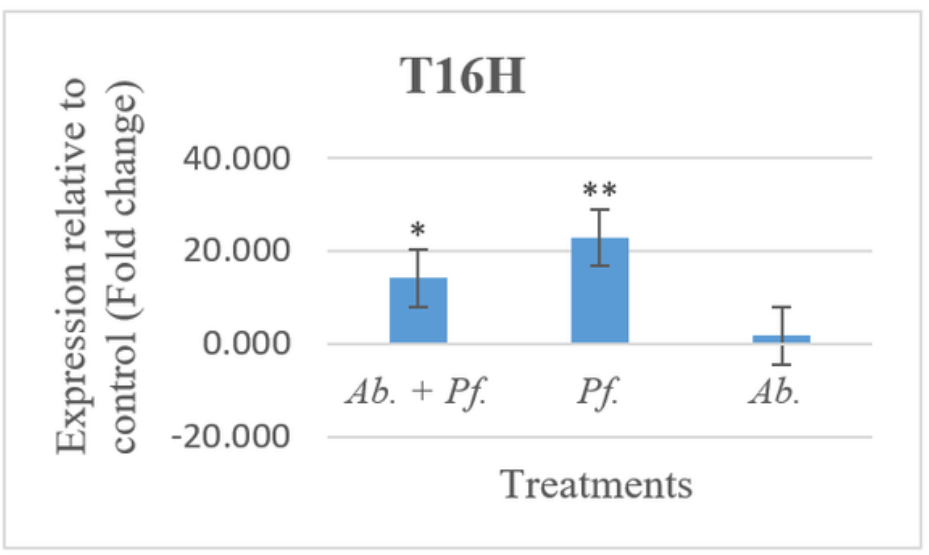

Dinal gene of the TIA biosynthetic
pathway

\section{CrPRX}

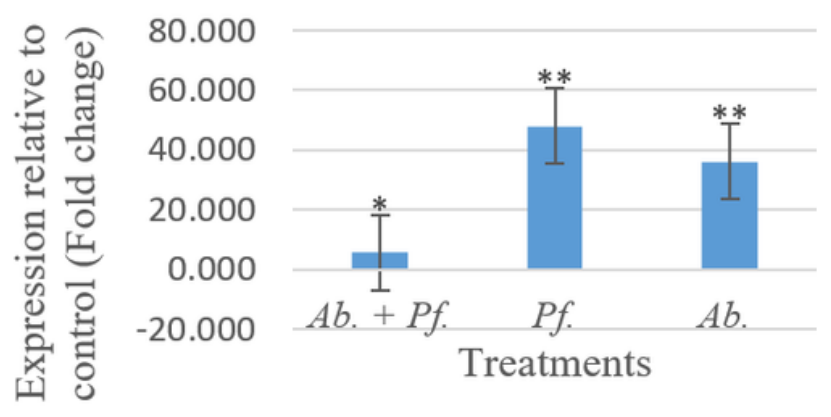

Figure 2

qRT-PCR expression analysis of G10H, T16H, DAT and CrPRX genes following treatment of C. roseus root with beneficial bacteria at three different concentrations. (P.F: P. fluorescens and A.b: A. brasilense) 


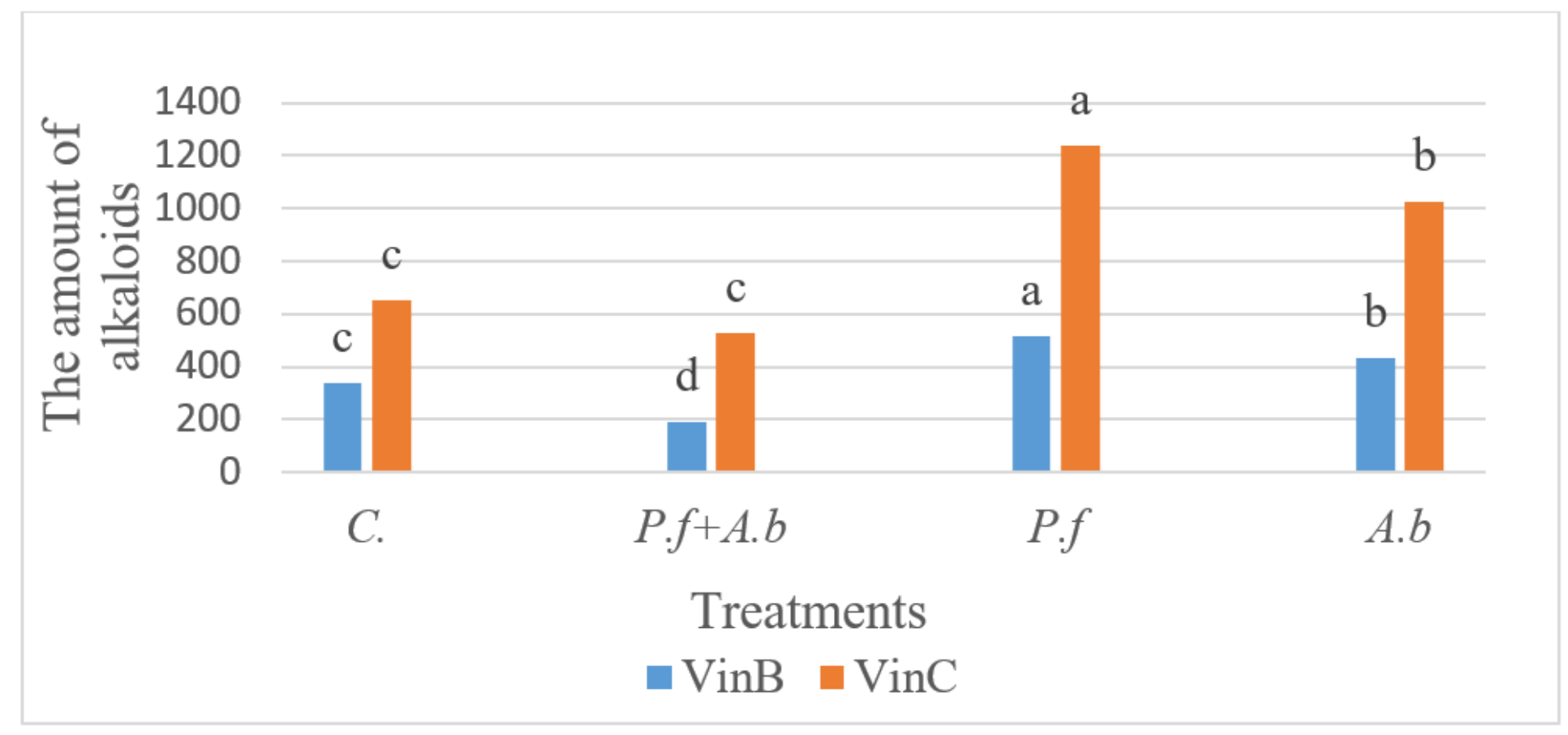

Figure 3

Comparison of the mean effects of bacterial inoculation treatments on the amount of two alkaloids vinblastine and vincristine in the roots of $\mathrm{C}$. roseus The same letters in each column indicate a significant difference in the $5 \%$ probability level. P.F: P. fluorescens and A.b: A. brasilense 